\title{
The Importance of Employer-to-Employer Flows in the U.S. Labor Market
}

by

Bruce C. Fallick ${ }^{*}$ and Charles A. Fleischman ${ }^{* *}$

April 2001

JEL code: J63, J64, J21, E24

Keywords: Gross flows, accessions, separations, on-the-job search, turnover

The views expressed in this paper are those of the authors and do not necessarily represent the views or policies of the Board of Governors of the Federal Reserve System or their staff. We thank seminar participants at the Board of Governors and the Federal Reserve Bank of Cleveland for helpful comments. We are especially grateful to staff at the Bureau of Labor Statistics and the Bureau of the Census for their assistance with the data, and to Siddhartha Chowdri and Paul Adler for excellent research assistance.

*Federal Reserve Board, Washington, DC 20551. (202)452-3722 bruce.fallick@ frb.gov

${ }^{* *}$ Federal Reserve Board, Washington, DC 20551. (202)452-6473 cfleischman@ frb.gov 


\begin{abstract}
In order to measure the flexibility of the labor market, evaluate the job-worker matching process, and model business-cycle dynamics, economists have studied the flows of workers across the labor market states of employment, unemployment, and not in the labor force. One important flow that has been poorly measured is the movement of workers from one employer to another without any significant intervening period of nonemployment. This paper exploits the “dependent interviewing" techniques used in the Current Population Survey since 1994 to estimate such flows. We find that they are large, and their omission significantly understates the degree of mobility in the labor market. In 1999, for example, on average more than 4,000,000 workers changed employers from one month to the next, about the same number as left the labor force from employment and more than twice the number moved from employment to unemployment.

Close to half of the new jobs started in 1999 represented employer changes, as did close to half of the separations. Consistent with previous studies of younger workers, teenagers exhibit the highest rates of employer-switching, and the rate declines through about age 40. However, even among prime-aged workers, about two percent change employers each month. Contrary to the implications of many business cycle models, we find no evidence that employerto-employer flows are procyclical, at least not as the labor market tightened between 1994 and 2000. This finding raises questions about the ways in which stylized facts about labor market flows have been used.
\end{abstract}




\section{Introduction}

The magnitude of worker flows across the labor market states of employment, unemployment, and not in the labor force swamp the net flows between these states. Marston (1976), most notably, used this fact about the gross flows to overturn the conventional wisdom that the U.S. labor market was quite inflexible, as had been suggested by the size of the net flows and the long average duration of spells of unemployment. One important flow that has been poorly measured is the movement of workers from one employer to another without any significant intervening period of nonemployment. As we will show, these flows are large, and their omission significantly understates the degree of job mobility in the U.S. labor market. For example, excluding employer-to-employer flows from the gross flow accounting understates the total numbers of both job accessions and separations by nearly half.

A large literature on the macroeconomics of the labor market has emphasized the role of gross flows of both workers and jobs. Much of this literature uses search and matching models, perhaps best exemplified by Mortensen and Pissarides (1994), to capture the dynamics of the labor market. Most early examples of this type of model ruled out on-the-job search and the consequent movement of workers directly from one employer to another - partly for analytical convenience, and partly because employer-to-employer flows were difficult to measure in the

aggregate. ${ }^{1}$ Tobin (1972) criticized the exclusion of on-the-job search from early search models; he argued that the restriction could only be justified if on-the-job search is substantially less efficient than searching while unemployed--which he did not believe it to be, at least for many occupations. Indeed, casual observation, and the occasional estimates of employer-to-employer flows that have appeared, suggest that excluding on-the-job search is important. ${ }^{2}$ Moreover, attempts to reconcile the models with the characteristics of gross flows among labor market states and of job creation and job destruction concluded that large and highly procyclical employer-to-employer flows (henceforth "EE" flows) are essential to explaining the observed

${ }^{1}$ Recognizing the empirical importance of quits (see note 2), the search models in Parsons (1973) and Burdett (1978) allowed for on-the-job search.

${ }^{2}$ Mattila (1974) found that about 60 percent of workers line up new jobs before leaving their old jobs; of course, not all workers moving directly from one employer to another without any intervening period of unemployment quit their prior job. See section V below. 
dynamics of the labor market (Burgess 1994, Mortensen 1994, Albaek and Sorensen 1998). In addition, ignoring on-the-job search can lead to mismeasurement of the parameters of the matching function, which are critical in many models of business cycle dynamics and of hysteresis (Anderson and Burgess 2000, van Ours 1995). Consequently, several more recent models of labor market dynamics include a prominent role for on-the-job search and associated movements from one employer to another without significant intervening unemployment (Mortensen 1994, Pissarides 1994, Davis and Haltiwanger 1999, Eriksson and Gottfries 2000, Petrongolo and Pissarides 2000).

More broadly, the potential for large EE flows is a critical premise underlying the literature that seeks to explain the presence of wage contracts as a way to reduce turnover-including an important class of efficiency-wage models (e.g., Bester 1989) and of models of implicit contracts whose enforcement depends upon internal reputation (e.g., Bull 1987). ${ }^{3}$

Unfortunately, the available estimates of EE flows used to calibrate the models or to compare with the models' implications have been unrepresentative of the population as a whole or only weakly related to the conceptual flows appropriate to the model. In short, despite the importance of EE flows to our understanding of labor market and business cycle dynamics, the literature lacks a comprehensive and representative measure of the size and character of these flows. ${ }^{4}$

In this paper, we provide such a measure of EE flows for the United States by exploiting the "dependent interviewing" techniques used in the Current Population Survey since 1994. We report two major findings. First, we find that EE flows are large, and their omission significantly understates the degree of mobility in the labor market. During an average month in 1999, more than 4,000,000 workers changed employers from one month to the next, about the same number

${ }^{3}$ Ironically, such models often rule out quitting to employment by assumption in order to concentrate on other incentive effects, but EE flows are the most natural "punishment" a firm faces for any loss of reputation among its existing work force.

${ }^{4}$ In contrast, considerable effort has been put into measuring flows of jobs between firms (most prominently, Davis, Haltiwanger, and Schuh 1996). However, as emphasized by Lane, Stevens and Burgess (1996), job flows and worker flows are not synonymous, either conceptually or empirically. 
as left the labor force from employment and more than twice the number who moved from employment to unemployment. Our data imply that an average of 2.7 percent of employed persons change employers each month - a higher fraction than has been sometimes used in calibration exercises. ${ }^{5}$ Similarly, on-the-job search appears to be an important element in hiring: Close to half of the new jobs started in 1999 represented employer changes, much higher than estimates made indirectly by Blanchard and Diamond (1989) or Pissarides (1994), and on-thejob search underlies a large percentage of EE moves.

Second, we find no indication that EE flows increased as the labor market tightened considerably between 1994 and 2000, and so find no evidence that EE flows are procyclical. Unfortunately, however, business cycle models typically concentrate on the differences between contractions and expansions (which are generally characterized by net job losses and net job gains, respectively), and have little to say about how flows should vary as the economy heats up within an expansion. Thus, the hypotheses to be found in the literature concerning the cyclicality of EE flows may not be directly applicable to the data we have available, which do not include a contraction. Nevertheless, we find that other flows in our data exhibit the cyclical properties found in the literature even over our short sample period, suggesting that the failure of EE flows to increase over this expansion constitutes a stylized fact with which the literature must come to terms. Moreover, we argue that the stylized facts used to generate the prediction that EE flows are procyclical may not be compatible. Specifically, we make explicit the assumptions implicit in the reasoning that relates job creation and job destruction to gross worker flows, and how violations of these assumptions can invalidate the inference of procyclical EE flows.

The paper proceeds as follows: In section 2, we review previous attempts to measure EE flows, and alternative data sources. In section 3, we describe the aspects of the redesigned CPS that we use to measure EE transitions. In section 4, we summarize the size and demographic variation in EE flows, and present a complete picture of gross worker flows. In section 5, we examine the relationship between on-the-job search and EE flows. In section 6, we describe the cyclical behavior of gross flows. Section 7 concludes, and is followed by an appendix describing the data (including its drawbacks) in greater detail.

${ }^{5}$ For example, Mortensen (1994) uses a value of 1.55 percent per quarter. 


\section{Previous Estimates ${ }^{6}$}

Estimates of the extent and character of employer-to-employer flows in the United States have been difficult to come by. Because convenient and representative data were lamentably scant until fairly recently, those studies that attempted to estimate EE transition rates were limited to using sectoral data, or data from which only rough inferences could be drawn. ${ }^{7}$

Blanchard and Diamond (1989) attempted to estimate EE flows by combining rough estimates of the quit rate in manufacturing ${ }^{8}$ with estimates of the fraction of quits that are followed by an EE flow. ${ }^{9}$ However, both components of this calculation come from intermittent data sources that are not representative of the population. In addition, of course, quits are not the only source of EE flows.

Blanchard and Diamond (1990) used the annual demographic supplement to the March CPS to estimate EE flow rates. The March CPS provides information on the number of different employers (up to three) that a person worked for during the previous year, as well as the number of spells of unemployment (up to three) during the previous year. With these data, Blanchard and Diamond constructed upper- and lower-bound estimates of EE flows at the annual

${ }^{6}$ The papers cited in this section are meant to represent the available sources of data; they are far from an exhaustive list of the studies that have attempted to estimate transition rates, retention rates, tenure distributions, and the like.

${ }^{7}$ For overviews of data sources, see Farber (1999) and Davis and Haltiwanger (1999a). For descriptions of some available sources of data for Europe, see Booth (1999); Burda and Wyplosz (1994); Galizzi and Lang (1998); Gregg and Wadsworth (1995); van Ours (1995); Jackman, et al (1989). For Canada, see Christofides and McKenna (1996). For Japan, see Hashimoto and Raisian (1985).

${ }^{8}$ They assumed that the quit rate in the manufacturing sector published by the BLS through 1981 was valid for the entire economy — an assumption that has not withstood scrutiny.

${ }^{9}$ Drawn from Akerlof, Rose, and Yellen (1988), who, in turn, drew from Bancroft and Garfinkle (1963), as well as their own tabulations from the National Longitudinal Survey of Mature Men. See also Matilla (1974), Marston (1976), and Fallick (1996) for estimates of EE flows following quits. 
frequency. Unfortunately, this information is not much to go on, and the range between their upper and lower bounds, as a fraction of employment, is about 10 percentage points. ${ }^{10}$

Several studies have calculated EE flows using the National Longitudinal Survey of Youth (NLSY) or the National Longitudinal Survey of Young Men. ${ }^{11}$ These sources are limited to younger workers, at least to date (even in 2000, the oldest workers in the NLSY are only 42, and the oldest persons in the NLS Young Men were 38 when survey ended), and are each limited to a single cohort, so that at no time can they provide a representative picture of the working population.

Ruhm (1990) used the Social Security Adminstration's Retirement History Longitundinal Survey to calculate EE transitions for persons who retire from their "career" jobs. These data could be used to calculate more general EE flows, but only for persons over age 57.

Numerous researchers have calculated rates at which workers separate from firms, or the related rates of retention or distributions of tenure, without particular regard to whether those separations are followed closely by employment with another employer. Ureta (1992) and Neumark, et al (1999), among others have used the occasional tenure supplements to the CPS (administered in 1963, 1967, 1969, 1975, 1979, 1983, 1987, 1991, 1996, and 1998) to look at job stability. Using either constructed synthetic cohorts across surveys, or the information about different age groups in each cross-sections, these authors estimated survival rates with an employer. However, this provides only a rough view of EE flows because one cannot distinguish between transitions to another employer and transitions to nonemployment.

Several of the sources of data that have been used to calculate survival or separation rates - including the Panel Study of Income Dynamics (PSID) and administrative data from the states' unemployment insurance systems - could be used to estimate EE flows. Each has of these data sources has own advantages and disadvantages. The PSID provides sufficient information to calculate EE flows at the annual, if not higher, frequency, and to link these flows to a rich set of information about the workers involved, including their employment histories. Unfortunately,

\footnotetext{
${ }^{10}$ See also Stewart (1999).

${ }^{11}$ For example, Parsons (1991), Farber (1994), Monks and Pizer (1998), Royalty (1998), Bernhardt, et al (1999), and Farber (1999).
} 
the PSID only asks the necessary questions about heads of households and their spouses, which leaves out large numbers of younger people, among whom EE flows are especially common (Polsky 1999). Administrative data from the unemployment insurance systems of various states allow one to follow workers across employers at the quarterly frequency -- so long as they remain within the state. But, at present, no researchers have assembled data for more than a handful of states (Anderson and Meyer 1994; Burgess, Lane, and Stevens 2000), and even these are not publicly available. Similar data that cover the entire country and are not constrained to in-state moves can be found in the Longitudinal Employee-Employer Data File, which contains quarterly Social Security earnings records for a large sample of persons from 1957 to 1972 (Topel and Ward 1992).

Perhaps the most attractive alternative source of data is the Survey of Income and Program Participation (SIPP). Each wave of the SIPP covers a four month period. For each wave, the SIPP provides information on which weeks a person was employed, was unemployed, or neither, the number of employers (up to three) and beginning and ending dates for up to two employers. In addition, employer identification numbers are assigned to up to two employers in each wave, and these numbers will remain the same if a person has the same employer in a subsequent wave. From this information, one could estimate monthly EE rates, and these flows could be linked to (short) longitudinal information about the workers as well as to information on the reason for the transition (Bansak and Raphael 1998; Gottschalk and Moffitt 1999).

\section{Employer-to-Employer Changes and Gross Flows in the CPS Data}

For the present study, we used matched monthly data from the basic monthly CPS covering the period from January 1994 to December 2000 to measure EE flows and other gross flows among labor market states. ${ }^{12}$ With the redesign of the CPS in January 1994, the Census Bureau began using dependent interviewing techniques. Rather than asking all respondents every question afresh in each month--which was a substantial burden on respondents as well as an important source of measurement errors--interviewers now ask some questions that refer back

\footnotetext{
${ }^{12}$ We adopt the following dating convention: We refer to a flow from month 1 to month 2 as a month 1 flow (e.g. a flow from January to February is a January flow). Accordingly, we use monthly CPS data for January 2001 to measure the December 2000 flows.
} 
to the answers given in the previous month. In particular, if a person is reported to be employed in one month and was reported to be employed in the previous month's survey as well, the interviewer asks the respondent whether the person still works for the same employer as reported in the previous month, where the interviewer reads out the employer's name from the previous month. If the answer is yes, then the interviewer carries forward the industry data from the previous month's survey; if the answer is no, then the respondent is asked the full series of industry, class, and occupation questions. ${ }^{13}$ We exploit this dependent interviewing in the redesigned CPS to characterize workers employed in two consecutive months as employer stayers or employer changes (EE) and construct a reliable estimate of EE flows.

In practice, a price one pays for frequent surveys is the need to rotate the sample before respondents resort to violence, which means that one can construct only a short panel using the matched CPS data: We can follow each individual for at most four consecutive months. This does not diminish the usefulness of these data for measuring gross flows in the aggregate, but does reduce our ability to control for heterogeneity that may influence individuals' transition rates. However, we can link data from the first through fourth interviews with those from the fifth through eighth interviews in order to partially control for unobserved individual characteristics, and can link our matched individuals to their information collected in the periodic supplements to the CPS, such as the March annual demographic supplements and the tenure supplements. We will pursue both these avenues in future work.

Although no source of data is superior to all others in all dimensions, we believe that the redesigned CPS is the best source of data on employer-to-employer transitions, and that it has several advantages over the other sources of data surveyed here. First, the CPS is representative of the entire civilian noninstitutional population in terms of age, geography, and other demographics. Second, the CPS data are the source of the official measures of unemployment and labor force participation; thus, our operational definitions of the gross flows correspond to the familiar concepts of employment, unemployment, and not in the labor force prevalent in the literature. Third, the CPS questionnaire goes into considerable detail, with careful probing, to

\footnotetext{
${ }^{13}$ Respondents who report no change in employer are asked whether their job duties remained the same as in the previous month.
} 
accurately determine each individual's labor market status. Fourth, the size of the sample in the CPS is considerably larger than in other household-based survey data, which allows for more detailed analyses. Fifth, the CPS survey is administered monthly, and asks about labor market experience in the previous week. This information should be easier to recall than information about the previous calendar year (as in the PSID or NLSY) or even about the previous four months (as in the SIPP). ${ }^{14}$

Of course, our measure of employer-to-employer transitions is not perfect. One deficiency that it shares with almost all attempts to measure transitions is that it may include as a single EE transition an employer change where there was an intervening period of nonemployment or multiple employers between survey dates. Respondents are interviewed during the week that includes the $19^{\text {th }}$ of each month about their labor market activities during the week including the $12^{\text {th }}$ of the month. ${ }^{15}$ Because of the gap between surveys, some workers who are employed during the reference periods in two successive months may have experienced some period of nonemployment between the reference weeks. We have no way of quantifying this effect, and classify all workers who report different employers in the two months as employer changers. Of course, the possibility that an individual changed employers several times between reference weeks - with or without intervening periods of nonemployment makes it difficult to sign, let alone estimate, the bias in our estimates of employer-changing rates, but at the monthly frequency of the CPS we do not regard this as a serious problem. ${ }^{16}$ In quarterly data, such as that drawn from UI or Social Security records, this problem is potentially much more severe: A person employed by one employer in one quarter and a different employer

\footnotetext{
${ }^{14}$ In a related vein, the CPS data become available within a couple of months of the survey, allowing for timely updates of the flows.

${ }^{15}$ Except in December--when the reference week and survey week are both moved earlier one week.

${ }^{16}$ In addition, our month-to-month measure of EE flows does not take account of workers who may return to a previous employer after a short temporary separation. Also, we define employer-changing with respect to a person's main job; a person holding multiple jobs simultaneously may be recorded as having changed employers if he separates from his main employer but remains employed at his second job.
} 
the following quarter may have experienced a long period of nonemployment between observations.

Other deficiencies, such as sample attrition, are discussed in the appendix.

\section{The Complete Picture of Gross Labor Market Flows}

Bleakely, Ferris and Fuhrer (1999), Blanchard and Diamond (1990), Poterba and Summers (1986), Davis and Haltiwanger (1999a) examine gross worker flows between employment (E), unemployment (U), and not in the labor force $(\mathrm{N})$. Table 1 presents our estimates of these flows as a percentage of the population for the years 1994 and 1996-2000. ${ }^{17}$ In the diagram, first-month labor force status is shown along the vertical axis and second month labor force status is shown along the horizontal axis. Each box represents a flow from one month to the next; the diagonal represents individuals who remain in the same state in both months. Roughly 2.5 percent of the relevant population, ${ }^{18}$ which would amount to about 5.2 million workers per month in 1999, moved from employment to nonemployment (that is, unemployment plus not in the labor force) in an average month, and a slightly higher number

\footnotetext{
${ }^{17}$ These tabulations, and those that follow in the rest of this section, exclude data from 1995 because the Census Bureau changed its household identification methodology between June 1995 and August 1995, and blocked out matches during these months for fear that respondents' confidentiality could be breached. Because of the strong seasonal component to the $\mathrm{EE}$ and other flows, we eliminated the entire calendar year from our basic sample out of concern that using only some months during 1995 could bias the estimates of gross flows.

${ }^{18}$ The civilian noninstitutional population aged 16 and over.
} 
moved from nonemployment to employment. ${ }^{19,20}$ Although these figures are large-especially when compared with average net monthly employment growth of 120,000 per month in 1999-they understate the full extent of job mobility because they exclude information on EE transitions.

\begin{tabular}{|c|c|c|c|c|}
\hline & Gross & $\begin{array}{r}\text { Table } 1 \\
\text { mong Lab } \\
\text { ercent of pc }\end{array}$ & $\begin{array}{l}\text { ket States } \\
\text { on) }\end{array}$ & \\
\hline & & & $\mathrm{e}$ in Second M & \\
\hline & & Employed & Unemployed & NLF \\
\hline State in First & Employed & 61.0 & 0.8 & 1.7 \\
\hline Month & Unemployed & 1.0 & 1.5 & 0.8 \\
\hline & NLF & 1.6 & 0.8 & 30.9 \\
\hline
\end{tabular}

We extend the standard analysis of gross labor market flows to include employer-toemployer flows in table 2. Conditional on being employed in the first month, a worker can be in one of four states in the second month: employed with the same employer (an employer stayer), employed with a new employer (an employer changer), unemployed, or not in the labor force. Likewise, conditional on being employed in the second month, a worker could have been in one

\footnotetext{
${ }^{19}$ In addition to allowing one to measure of EE transitions, the redesigned CPS goes into considerable detail to establish each individual's correct labor market status. The increased probing has produced smaller--and presumably better--estimates of gross flow rates across labor market states. Indeed, Bleakley, Ferris, and Fuhrer (1999) provide time series plots of the gross flow rates over the period from January 1976 to March 1999, which show a notable drop-off beginning in 1994 - even as compared with the pre-1994 flow rates adjusted using the AbowdZellner (1985) factors.

${ }^{20} \mathrm{We}$ found that rotation groups one and five had higher rates of EE changing and flows out of employment. Given that this is consistent with the well-documented "rotation group bias" in the CPS, we have decided to feature the results excluding these rotation groups. We discuss the rotation group bias more completely in the appendix, where we also report results including the first and fifth months groups.
} 
for four states in the first month: employed with the same employer, employed with a different employer, unemployed, or not in the labor force. To accommodate the added state, "still employed/new employer," we added a fourth column. Adding the employer-to-employer flows increases the number of employment separations (the sum of the flows from employment to nonemployment and from one employer to another) and accessions (the sum of flows from nonemployment to employment and from one employer to another) by more than half.

\begin{tabular}{|c|c|c|c|c|c|}
\hline \multicolumn{6}{|c|}{$\begin{array}{c}\text { Table } 2 \\
\text { Gross Flows Among Labor Market States } \\
\text { (as a percent of population) }\end{array}$} \\
\hline & & \multicolumn{4}{|c|}{ State in Second Month } \\
\hline & & $\begin{array}{c}\text { Same } \\
\text { Employer }\end{array}$ & $\begin{array}{c}\text { New } \\
\text { Employer }\end{array}$ & Unemployed & NLF \\
\hline \multicolumn{6}{|c|}{ As a percent of population } \\
\hline \multirow{3}{*}{$\begin{array}{l}\text { State in First } \\
\text { Month }\end{array}$} & Employed & 59.3 & 1.7 & 0.8 & 1.7 \\
\hline & Unemployed & -- & 1.0 & 1.5 & 0.8 \\
\hline & NLF & -- & 1.6 & 0.8 & 30.9 \\
\hline \multicolumn{6}{|c|}{ As a percent of state in first month } \\
\hline \multirow{3}{*}{$\begin{array}{l}\text { State in First } \\
\text { Month }\end{array}$} & Employed & 93.3 & 2.7 & 1.3 & 2.7 \\
\hline & Unemployed & -- & 29.8 & 46.3 & 23.9 \\
\hline & NLF & -- & 4.7 & 2.4 & 92.9 \\
\hline
\end{tabular}

All in all, 6.7 percent of all employee-employer matches (“jobs”) were dissolved in an average month, and 6.8 percent of all matches in an average month were new, compared with average net employment growth of only 0.2 percent per month in these years. On average, 2.7 percent of employed workers leave one employer for another each month - about 40 percent of the total number of employer separations -- about the same size as the EN flow and double the EU flow. Similarly, about 40 percent of the workers accessing to a new employers did so 
straight from a previous employer. Clearly, excluding EE transitions from an analysis of gross labor market flows misses a large part of the mobility in the US labor market.

\section{Group differences in gross flows}

A well-known feature of the labor market is that the frequency of labor force transitions varies greatly over the life-cycle and across demographic groups. We find that EE flows vary considerably less than other flows. As a result, overall turnover differs less across groups once one takes account of EE movements.

As shown in figure 1, the monthly separation rate (separations as a percent of employment) falls through about age 40, as workers settle into jobs, and begins to rise as retirement becomes more common near to age 60. Similarly, the percentage of employment at each age that represents new accessions falls sharply through the mid-20s and begins to rise as retirements increase. However, the degree of churning - job-shopping and the like - is better represented by the EE rates shown in the top panel of the figure. While researchers have repeatedly demonstrated that the rate of employer-to-employer movement declines sharply through about age 30, less well known is that the EE rate shows little change from about age 40 on. ${ }^{21}$ Thus, the contribution of workers in the youngest age groups to the total number of EE transitions is about twice their share of employment, but by middle age their EE share has stabilized at about 2/3 their employment share, and remains there even as the age group's relative contribution to separations and accessions begins to rise (table 3 ).

Moreover, EE flows decline with age more slowly than do other forms of separation. Because EE flows vary less with age than do other labor market transitions, the bulk of the age differences in measures of job stability based on separation rates (e.g. Jaeger and Stevens 1999, Neumark, et al 1999) stem from departures to nonemployment rather than employer changes.

${ }^{21}$ There is little difference in the overall separation and accession rates between young men and women, although young men are more likely to move to make EE or EU transitions and are less likely to move E to N. Royalty (1998) finds similar differences between the turnover patterns of men and women in the NLSY. 


\begin{tabular}{||c|c|c|c|c|}
\hline \multicolumn{5}{|c|}{ Table 3 } \\
\hline Pge Group & Employment & $\begin{array}{c}\text { Separations } \\
\text { (EE+EU+EN) }\end{array}$ & EE & $\begin{array}{c}\text { Accessions } \\
\text { (EE+UE+NE) }\end{array}$ \\
\hline $16-19$ & $5.2 \%$ & $16.1 \%$ & $11.6 \%$ & $21.1 \%$ \\
\hline $20-24$ & 9.4 & 16.4 & 17.4 & 16.4 \\
\hline $25-34$ & 23.9 & 21.8 & 26.2 & 19.5 \\
\hline $35-44$ & 27.6 & 19.2 & 22.0 & 17.3 \\
\hline $45-54$ & 21.0 & 12.9 & 14.2 & 11.4 \\
\hline $55-64$ & 9.8 & 8.2 & 6.7 & 7.7 \\
\hline 65 and over & 3.0 & 5.3 & 2.0 & 6.6 \\
\hline \hline Total & 100 & 100 & 100 & 100 \\
\hline
\end{tabular}

Note: EE refers to employer-to-employer flows, EU to employment to unemployment flows, EN to employment to not-in-the-labor-force flows, UE to unemployment to employment flows, and NE to not-in-the-labor-force to employment flows.

In a similar fashion, EE flows reduce the differences between men and women in separation and accessions rates. Women separate from their employers more often overall (much of which is due to higher rates of leaving the labor force) but move from one employer to another a bit less often than do men. Table 4 summarizes flows for these and other demographic breakdowns. Nonwhite workers separate from their employers at higher rates than do whites, but have similar EE rates. Both total separation rates and EE transition rates fall with the workers' level of education, but EE rates fall much more slowly. 


\begin{tabular}{|c|c|c|c|c|}
\hline \multicolumn{5}{|c|}{$\begin{array}{c}\text { Table } 4 \\
\text { Transitions as a Percent of Employment, by Demographic Characteristics }\end{array}$} \\
\hline & & $\begin{array}{c}\text { Separations } \\
(\mathrm{EE}+\mathrm{EU}+\mathrm{EN}) \\
\end{array}$ & $\mathrm{EE}$ & $\begin{array}{c}\text { Accessions } \\
(\mathrm{EE}+\mathrm{EU}+\mathrm{EN}) \\
\end{array}$ \\
\hline \multirow{3}{*}{ Age } & $16-24$ & $14.8 \%$ & $5.4 \%$ & $15.6 \%$ \\
\hline & $25-54$ & 5.0 & 2.3 & 5.0 \\
\hline & 55 and over & 7.0 & 1.8 & 6.4 \\
\hline \multirow{2}{*}{ Sex } & female & 7.1 & 2.6 & 7.2 \\
\hline & male & 6.3 & 2.8 & 6.3 \\
\hline \multirow{2}{*}{ Race } & nonwhite & 7.8 & 2.7 & 7.8 \\
\hline & white & 6.4 & 2.7 & 6.5 \\
\hline \multirow{5}{*}{ Education } & $<$ high school & 12.0 & 3.5 & 12.6 \\
\hline & high school & 6.6 & 2.7 & 6.5 \\
\hline & some college & 6.5 & 2.9 & 6.6 \\
\hline & college & 4.6 & 2.4 & 4.6 \\
\hline & $>$ college & 3.9 & 2.0 & 3.8 \\
\hline
\end{tabular}

Table 5 summarizes flows for different breakdowns of job characteristics. Full-time workers (those reporting that they usually worked 35 or more hours on their main job) show greater job stability than do part-time workers, but, as with education, the EE rates differ considerably less than do the rates of other types of separations. In keeping with conventional wisdom, government workers are less likely to separate from their employers than are workers in the private sector; this includes lower EE rates. Within the private sector, self-employed workers have slightly higher separation rates and slightly lower EE rates as do those who work for 
someone else. ${ }^{22}$ We should note that although most of the self-employed workers who report an EE transition move out of self-employment, a significant number remain self-employed, in which case the economic meaning of the transition is less clear. Also within the private sector, the agriculture, construction, retail, and private household services industries have particularly high EE rates.

\section{On-the-Job Search}

Lacking direct measures of EE flows, some researchers have estimated EE flows as the fraction of workers who quit from employment after having already lined up another job. ${ }^{23}$ However, defining EE flows as resulting only from quits, presumably following on-the-job search, will underestimate the extent of EE flows. We find that only about one-fifth of EE changers engaged in active on-the-job search in the three months prior to the move, a smaller fraction than -- but still not too different from -- the approximately one-third of newly employed workers who were unemployed in the prior month.

\footnotetext{
${ }^{22}$ For our purposes, we group the incorporated and the unincorporated self-employed together, in contrast to official BLS statistics, which include the incorporated self-employed in private wage \& salary workers.

${ }^{23}$ For example, Matilla (1974), Tobin (1972), and Blanchard and Diamond (1989).
} 


\begin{tabular}{|c|c|c|c|c|}
\hline \multicolumn{5}{|c|}{$\begin{array}{c}\text { Table } 5 \\
\text { Transitions as a Percent of Employment, by Job Characteristics }\end{array}$} \\
\hline & & $\begin{array}{c}\text { Separations } \\
(\mathrm{EE}+\mathrm{EU}+\mathrm{EN}) \\
\end{array}$ & $\mathrm{EE}$ & $\begin{array}{c}\text { Accessions } \\
(\mathrm{EE}+\mathrm{UE}+\mathrm{NE}) \\
\end{array}$ \\
\hline \multirow{2}{*}{ Work Schedule } & part-time & 13.2 & 4.2 & 13.7 \\
\hline & full-time & 4.7 & 2.3 & 4.7 \\
\hline \multirow{3}{*}{ Class } & government & 4.3 & 1.7 & 4.4 \\
\hline & private employees & 7.0 & 3.0 & 7.2 \\
\hline & self-employed & 7.2 & 2.5 & 6.9 \\
\hline \multirow{10}{*}{ Industry } & agriculture, etc. & 11.5 & 3.6 & 11.1 \\
\hline & mining & 4.7 & 2.4 & 4.6 \\
\hline & construction & 8.9 & 3.7 & 9.0 \\
\hline & manufacturing & 4.6 & 1.9 & 4.5 \\
\hline & TCPU & 4.6 & 2.1 & 4.8 \\
\hline & wholesale trade & 4.9 & 2.3 & 5.1 \\
\hline & retail trade & 9.2 & 3.7 & 9.3 \\
\hline & FIRE & 4.8 & 2.4 & 4.9 \\
\hline & $\begin{array}{l}\text { Private } \\
\text { Households }\end{array}$ & 20.2 & 4.8 & 19.9 \\
\hline & Other Services & 6.7 & 2.7 & 6.9 \\
\hline
\end{tabular}

We construct a dataset that includes information on both on-the-job search and labor market flows by linking our monthly matched CPS data with the information on job-search behavior by employed workers collected in the contingent worker supplements to the February 
1997 and February 1999 CPS. $^{24}$ For workers employed more than three months, the survey supplement asks (in mid-February), "Since the beginning of December, have you looked for other employment?" For workers employed at most three months with their current employer, the survey asks "Since you started working for [fill: employer's name from basic CPS], have you looked for other employment?" The supplement differentiates between active search and passive methods of search, using the same definitions as the basic CPS uses in determining whether an individual is unemployed. ${ }^{25}$ The survey also differentiates between those looking for a new job or an additional job. By analogy with the CPS definition of unemployment (excluding those on temporary layoff), we consider only those workers actively looking for a new job as onthe-job searchers.

Table 6 reports on the March labor force status of individuals employed in February 1997 and 1999, differentiated by on-the-job search behavior. Of those employed in February, 4.4 percent had engaged in active on-the-job search. These job-seekers were much more likely to have changed employers between February and March: 11.3 percent of on-the-job searchers reported a new employer in March, compared with 2.1 percent of employed workers who had not actively engaged in search. Searchers were also more likely to have become unemployed in March, where they presumably continued their search for a new job - 5.6 percent for searchers vs. 0.9 percent for non-searchers. Searchers were no more likely than nonsearchers to leave the labor force.

\footnotetext{
${ }^{24}$ See Meisenheimer and Ilg (2000) for a more complete description of the survey questions and for descriptive statistics on the extent of on-the-job search; these authors do not address the outcomes of on-the-job search.

${ }^{25}$ Specifically, the supplement asks, "What are all of the things you have done to find other employment ... ?" Active search includes contacting an employer directly, contacting a public or private employment agency, contacting friends or relatives, contacting a school employment center, sending out resumes or filling out applications, checking union or professional registers, or placing or answering a want advertisement. Passive search includes looking at advertisements or attending a job training course.
} 


\begin{tabular}{|l|c|c|c|c|}
\hline \multicolumn{5}{|c|}{ Table 6} \\
Flow Rates for Employed Workers in February 1997 and 1999 by On-the-Job \\
Search Behavior (as a percent of employment)
\end{tabular}

Table 7 reports on the importance of on-the-job search in overall labor market flows. It is analogous to table 2, except that in table 7 we divide employed workers into on-the-job searchers and non-searchers and we report only on the flows between February and March 1997 and 1999. ${ }^{26}$ As shown in the table, on-the-job search between the beginning of December and mid-February (or since the job held in February began--whichever is shorter) was associated with about 20 percent of all EE changers; thus, 80 percent of the EE changers between February and March did not engage in any active on-the-job search, at least through the February reference week.

\footnotetext{
${ }^{26}$ Not all individuals employed in February 1997 and February 1999 had valid responses to the supplement questions. There are small differences in composition between the full sample of February-March matches and that restricted to valid supplement responses in February; in particular, the supplement reports that 2.5 percent of employed workers in February held a different job at the March reference period compared with a 2.6 percent EE rate for the broader sample. We calculated the rates in table 7 by multiplying each of the overall flow rates based on the full February-March matches by the share of the appropriate group that engaged in on-thejob search in the February supplements.
} 


\begin{tabular}{|l|c|c|c|c|}
\hline \multicolumn{5}{|c|}{ Gable 7 } \\
& $\begin{array}{c}\text { New } \\
\text { Employer }\end{array}$ & $\begin{array}{c}\text { Employer } \\
\text { Stayer } \\
\text { (or Employed) }\end{array}$ & Unemployed & $\begin{array}{c}\text { Not in the } \\
\text { Labor Force }\end{array}$ \\
\hline Employed & 1.6 & 59.2 & 0.7 & 1.4 \\
\hline \multicolumn{1}{|c|}{ On-the-job search } & 0.3 & 2.2 & 0.2 & 0.1 \\
\hline No on-the-job search & 1.3 & 57.0 & 0.5 & 1.4 \\
\hline $\begin{array}{l}\text { Unemployed (not on } \\
\text { temporary layoff) }\end{array}$ & -- & 0.7 & 1.4 & 0.7 \\
\hline $\begin{array}{l}\text { Unemployed (on } \\
\text { temporary layoff) }\end{array}$ & -- & 0.3 & 0.3 & 0.1 \\
\hline Not in the Labor Force & -- & 1.5 & 0.8 & 31.3 \\
\hline
\end{tabular}

On its face, the relatively small share of EE flows explained by on-the-job search may seem odd. However, while EE changers who engaged in on-the-job search are in the minority, the same is true of newly employed workers in March who had reported that they were actively searching for a job at the time of the February survey. Only about one-third of the movers from non-employment (excluding those on temporary layoff) to employment reported themselves as unemployed, which means actively searching, in February. Thus, the contributions of on-the-job search and off-the-job search in explaining flows into new jobs from other jobs and from nonemployment, respectively, appear to be of similar importance.

Moreover, there are reasons to believe that our estimate understates the share of EE changers who had looked for a new job while employed. First, because our measure of on-thejob search only captures search prior to the first month of each matched observation, we do not pick up any job-seeking behavior between the February and March reference weeks. Second, many EE changes involve geographic moves; because the CPS is an address-based survey, a 
person who moves out of an address to be closer to a new job will not be counted as a jobchanger in our sample. ${ }^{27}$

\section{The Cyclical Properties of Gross Flows}

As we mentioned in section I, the business cycle literature has, until now, lacked a reliable and representative measure of the frequency of EE flows to which models may be calibrated and their simulation results compared. In section IV, we provided such a measure of the level of EE flows, and found that level to be higher than the indirect measures typically used in the literature. In this section, we examine another aspect of EE flows often used in modeling exercises: how EE flows change over time.

The literature has established several stylized facts about the behavior of gross flows across labor market states over the business cycle. ${ }^{28}$ Several of these empirical regularities are as follows, where flows are viewed as a percentage of the population, rather than as hazard or transition rates:

1. The flow into unemployment is countercyclical.

2. The flow out of unemployment is countercyclical. ${ }^{29}$

3. The cyclicality of the flow into employment is unclear; it combines a countercylical flow from unemployment to employment with a procyclical flow from NLF to employment.

4. The flow out of employment is probably countercyclical in the U.S., but if so only weakly; in Europe it appears to be procyclical.

\footnotetext{
${ }^{27}$ In addition, contacts initiated by another employer may not be classified as on-the-job search in our data, and seasonal jobs that had been lined up well in advance of the start date would not be counted in these data as involving search. Note that these reasons may also apply to the share of the nonemployed who report active search, that is, to unemployment.

${ }^{28}$ See, for example, Blanchard and Diamond (1990), Burda and Wyplosz (1994), Mortensen (1994), and Merz (1999).

${ }^{29}$ The hazard rate for leaving unemployment is procyclical, but the countercylicality of the size of the pool of unemployed is the dominant factor.
} 
Several researchers have concluded that reconciling these flows with the stylized facts about job creation and job destruction require that EE flows be large and highly procyclical. (We will detail their arguments below.) Accordingly, some have followed a model-building strategy that aims, in part, at accommodating these properties. ${ }^{30}$ We have shown above that EE flows are large; the question of cyclicality is more difficult. Our data cover only the 1994-2000 period, and so do not include a contraction. Still, during this period of strong expansion, the labor market tightened considerably. The annual average unemployment rate decreased a bit more than 2 percentage points between 1994 and 2000 (from 6.1 percent to 4 percent), a slightly larger spread than the increase in the unemployment rate associated with the 1990-91 recession. We begin by showing that the other flows across labor market states have moved in accordance with the stylized facts concerning their cyclicality over this period of labor market tightening; from this we conclude that it is reasonable to think that the behavior of EE flows over this period is also indicative of their general cyclical behavior.

Figure 2 shows the pattern of the flows into and out of the labor market states of unemployment, employment, and out of the labor force in our data over the years 1994 to $2000 .^{31}$ The figure demonstrates that even within our short sample period, our data are consistent with the stylized facts about gross worker flows. As shown in the top panels, we find that the flows into and out of unemployment both exhibit clear countercyclical tendencies. In contrast, the flow into employment follows no clear cyclical pattern, falling as the labor market tightened and then rising, and in either case not by much. This while its components (shown the top panels of figure 3) follow the expected course: The flow from unemployment to employment is strongly countercyclical and the flow from NLF to employment is roughly procyclical. The flow out of employment, which is at best only weakly countercyclical in the literature, is ambiguous in our data, as well, declining for the first couple of years of our sample before increasing for the last couple of years.

${ }^{30}$ For example, Pissarides (1994) and Petrongolo and Pissarides (2000).

31 Because not all months in 1995 are represented in our matched data, we regressed the monthly flow rates on month and year dummies, and report the coefficients on the year dummies with the mean of the coefficients on the month dummies added back in. 
To further evaluate the stylized facts, we exploited an additional source of business cycle variation: the substantial differences across states in the degree and timing of labor market tightening. For example, the declines in published unemployment rates between April 1994 and April 2000 range from no decline at all in Montana, to 1.2 percentage points in South Carolina, to 2.7 percentage points in New York, to 3.9 percentage point in California, to 4.6 percentage points in Maine. Table 8 reports estimated coefficients from regressions of the state-level flows on the unemployment rate, with state fixed-effects removed. The state-level results generally accord well with the stylized facts, confirming the impressions from figure 2. The state-level estimates shown in columns 1 and 2 indicate that both the flows into unemployment and the flows out of unemployment are strongly countercyclical. As shown in the third column, the flow into employment appears weakly countercyclical in the state data, thus suggesting that the countercyclical flow from unemployment to employment slightly outweighs the procyclical flow from out of the labor force to employment. We find that a one percentage point increase in the unemployment rate is associated with a mere 0.04 percentage point increase in the flows into employment (as a percentage of the population). The regression of the flows out of employment on the unemployment rate show them to be acyclical, as in the aggregate data.

\begin{tabular}{|l|c|c|c|c|}
\hline \multicolumn{5}{|c|}{$\begin{array}{c}\text { Table 8 } \\
\text { Regression Estimates of State-Level Flows on the Unemployment Rate } \\
\text { (Fixed Effects Removed) }\end{array}$} \\
\hline & Flows Into U & Flows Out of U & Flows Into E & Flows Out of E \\
\hline $\begin{array}{l}\text { Unemployment } \\
\text { Rate }\end{array}$ & 0.19 & 0.23 & 0.04 & -0.00 \\
\hline (Std. Error) & $(0.01)$ & $(0.01)$ & $(0.01)$ & $(0.01)$ \\
\hline
\end{tabular}

Several authors have argued that when these facts on gross flows are combined with the stylized facts concerning job creation and job destruction (drawn from data on net changes in employment at establishments), paradoxes arise that can be resolved most naturally by procyclical EE flows. For example, Mortensen (1994) argues that in the absence of procyclical EE flows, the procyclicality of job creation is difficult to reconcile with the absence of 
procyclical flows into employment, especially in a framework that abstracts from direct NE flows. Similarly, Albaek and Sorensen (1998) observe that without procyclical EE flows, the strong countercylicality of job destruction is difficult to reconcile with the weak countercyclicality of flows out of employment. They also observe that replacement hiring is procyclical in their data, which strongly suggests that EE flows are procyclical.

These arguments can be made more precise by expressing job creation and job destruction as functions of the gross worker flows. The typical definition of job creation (JC) is the sum of net employment changes at establishments where the net change is positive. Similarly, job destruction (JD) is typically defined as the sum of net employment changes at establishments where the net change is negative. In terms of worker flows,

$J C=\left(N E_{+}+U_{+}\right)-\left(E_{+} N+E_{+} U\right)+\left(E_{+}-E_{+} E\right)$

and

$\mathrm{JD}=\left(\mathrm{E}_{-} \mathrm{N}+\mathrm{E}_{-} \mathrm{U}\right)-\left(\mathrm{NE}_{-}+\mathrm{UE}_{-}\right)+\left(\mathrm{E}_{-} \mathrm{E}_{-} \mathrm{EE}_{-}\right)$,

where $\mathrm{E}_{+}$refers to employment at establishments with positive employment changes and $\mathrm{E}_{-}$ refers to employment at establishments with negative employment changes. That is, job creation is the sum of flows into employment at expanding establishments, $\left(\mathrm{NE}_{+}+\mathrm{UE}_{+}\right)$, minus flows out of employment at expanding establishments, $\left(\mathrm{E}_{+} \mathrm{N}+\mathrm{E}_{+} \mathrm{U}\right)$, plus net employer-to-employer flows into and out of expanding establishments, $\left(\mathrm{EE}_{+}-\mathrm{E}_{+} \mathrm{E}\right)$. Job destruction, on the other hand, is the sum of flows out of employment at declining establishments, (EN + E_U), minus flows into employment at declining establishments, (NE_ + UE_), plus net employer-to-employer flows into and out of declining establishments, (E_E - EE_.). Thus, a complete accounting for the flows associated with job creation and job destruction makes the distinction between inflows and outflows at expanding and contracting establishment, and allows for the possibility of significant flows out of employment at expanding firms and flows into employment at contracting firms.

Attempts to reconcile gross worker flows with the job creation and job destruction stylized facts, however, have typically made important simplifications to (1) and (2). Mortensen 
(1994), for example, abstracts from both the flows out of expanding establishments and the flows into declining establishments. Mortensen uses a simplified accounting framework where

$\mathrm{JC}=\left(\mathrm{NE}_{+}+\mathrm{UE}_{+}\right)+\mathrm{EE}$

and

$\mathrm{JD}=\left(\mathrm{E}_{-} \mathrm{N}+\mathrm{E}_{-} \mathrm{U}\right)-\mathrm{EE}$

As we have seen, the different cyclical properties of the flows into and out of employment involving $U$ and those involving $N$ leave the bracketed terms in (1') and (2') only weakly cyclical. Thus, to square with the pronounced cyclicality of job creation and job destruction, EE flows must be strongly procyclical.

The conclusion that EE flows must be procyclical, however, does not necessarily rely on such strong simplification. The full accounting shown in (1) and (2) also implies procyclical EE flows if one assumes 1) that the relative size and cyclical properties of the NE, UE, EN, and EU flows do not depend upon whether one confines attention to expanding or contracting establishments; and 2) that $\mathrm{EE}_{+}$flows dominate $\mathrm{E}_{+} \mathrm{E}$ flows, and, similarly, that EE flows dominate EE flows; that is that EE flows involving growing establishments are primarily flows into those establishments and EE flows involving shrinking establishments are primarily flows out of those establishments. Under these assumptions, the aggregate worker flows can be used to represent each of the components in (1) and (2), and, therefore, the cyclical properties of the gross worker flows can be compared to the cyclical properties of the net job flows. Then, because the flows into and out of employment - the first two bracketed terms in (1) and (2) exhibit only weak cyclicality, procyclical job creation and countercyclical job destruction both require procyclical EE flows.

Accordingly, in keeping with the literature, we would expect EE flows to increase over our sample period. However, such is not the case. The EE flows in figure 4 exhibit no obvious cyclical pattern, falling initially as the labor market tightened, and then rising again more recently. Again, we turned to state data to support our findings based on the aggregate flows. 
And, as with the aggregate data, the state-level variation in EE flows between 1994 and 2000 does not provide any evidence of procyclicality. Table 9 reports estimated coefficients from regressions of the state-level flows on the unemployment rate, with state fixed-effects removed, that are analogous to those reported in table 8. As shown in the first column, a one percentage point increase in a state's unemployment rate is associated with essentially no change in the EE flow rate (as a percentage of the population), and the coefficient is not statistically significant. ${ }^{32}$

\begin{tabular}{|l|l|l|l|l|l|l|l|}
\hline \multicolumn{7}{|c|}{$\begin{array}{c}\text { Table 9 } \\
\text { Regression Estimates of State-Level Flows on the Unemployment Rate } \\
\text { (Fixed Effects Removed) }\end{array}$} \\
\hline & EE & EU & UE & EN & NE & NU & UN \\
\hline $\begin{array}{l}\text { Unemployment } \\
\text { Rate }\end{array}$ & 0.01 & 0.07 & 0.10 & -0.07 & -0.06 & 0.12 & 0.13 \\
\hline $\begin{array}{l}\text { (Std. Error) } \\
\text { Note: EE refers to employer-to-employer flows, EU to employment to unemployment flows, EN to employment } \\
\text { to not-in-the-labor-force flows, UE to unemployment to employment flows, and NE to not-in-the-labor-force to } \\
\text { employment flows. }\end{array}$ \\
\hline
\end{tabular}

Again, our data cover only the expansionary phase of the business cycle, but we can conclude that if EE flows do exhibit the great procyclicality that the literature requires, it must be concentrated around the recessions and the early stages of recoveries; we see no evidence of procyclicality during the recent expansion. Unfortunately, when matching business cycle models to the empirical facts, there has been little attempt to distinguish between a model's

${ }^{32}$ As with the aggregate data, the regression results for the other flows using the state data match up well with the stylized facts. The second and third columns of table 8 show the coefficients from regressions of the EU flow rate and the UE flow rate, respectively. As expected, both of these flows are strongly countercyclical, with a one percentage point increase in the unemployment rate lowering the EU and UE rates by 0.07 and 0.1 percentage point, respectively. Conversely, as shown in the remaining columns, the EN and NE flow rates are procyclical, and the NU and UN flow rates are countercyclical. Of course, the same caveats apply here as to our analysis of the cyclicality of flows using the aggregate data. 
implications for differences between expansions and recessions and its implications for changes within expansions or recessions - especially around cyclical turning points. Summary statistics concerning variation in flows are likely to be dominated by the contrasts between expansion and recession, so the hypotheses generated by the literature may be more applicable to comparisons between phases of the business cycle than to comparisons within a phase.

While we recognize the limitations imposed by our sample period, we maintain that our data provide the best evidence to date on the cyclical properties of EE flows. ${ }^{33}$ One must, then, ask how to reconcile this lack of cyclicality with the literature. One possibility, of course, is that the data that gave rise to the stylized facts concerning job creation and job destruction do not generalize to the economy as a whole. An alternative is that the assumptions necessary to equate net job flows with gross worker flows are violated.

In particular, assumption \#1 above - that the relative size and cyclical properties of the components of the flows into and out of employment are the same for contracting and expanding establishments - is problematic. Violations of this assumption may explain why EE flows are not procyclical. For example, the $\mathrm{UE}_{+}$flow may be procyclical, or at least less countercyclical than the UE flow. In this case, the $\mathrm{NE}_{+}$and the $\mathrm{UE}_{+}$flows may not cancel out, as do the overall $\mathrm{NE}$ and UE flows. Or, the $\mathrm{NE}_{+}$flow may simply outweigh the $\mathrm{UE}_{+}$flow, while the opposite is true for contracting establishments. In addition, the flows out of employment at expanding firms and the flows into employment at contracting firms may be quite large. ${ }^{34}$

We believe that our findings have important implications for the continued development of business cycle models. First, researchers should take great care in combining the results of the

${ }^{33}$ Perhaps the most frequently cited evidence of procyclical EE flows is Blanchard and Diamond (1989), which is based on the procyclicality of quit rates in manufacturing (see above). To our knowledge, ours is the first direct evidence on the cyclicality of aggregate EE flows in the U.S..

${ }^{34}$ For example, Hamermesh, Hassink, and van Ours (1994) found that for a representative sample of Dutch firms in 1988 and 1990, the separation rate at expanding firms averaged 9.8 percent of their employment, while the hiring rate at contracting firms averaged 5.9 percent of their employment; indeed, based on these figures, only 58 percent of all hires take place at expanding firms and only 40 percent of all fires (layoffs plus discharges for cause) take place at contracting firms. 
job creation/job destruction literature with information on gross worker flows. In particular, more research needs to be directed to the possibility that the patterns of gross worker flows may differ according to whether establishments are expanding or contracting. ${ }^{35}$ Second, researchers should pay greater attention to how the implications of business cycle models for labor market dynamics vary according to the phase of the business cycle, and, as a corollary, to the period of the data to which the models are applied.

\section{Conclusion}

In this study, we exploited the "dependent interviewing" techniques in the redesigned Current Population Survey to estimate employer-to-employer flows over the period 1994 to 2000. We found that these flows are a large and important element of the overall the mobility in the U.S. labor market. However, we found no evidence that employer-to-employer flows are procyclical, at least during the 1994-2000 period for which we have data.

These data raise several questions that we intend to pursue in future work, beyond further study of the cyclical variation in gross flows. One such question is the role of employer-toemployer flows in the sectoral reallocation of labor. This role is important for understanding how reallocation contributes to equilibrium unemployment, and the relationship between reallocation and the business cycle (Lilien 1982, Fallick 1996). Our preliminary work indicates that about one-third of structural reallocation, defined as the variance in seasonally-adjusted net employment growth across 2-digit industries, is accomplished through employer-to-employer flows. In addition, these data should prove useful in studying the determinants of job mobility and the tremendous seasonality characteristic of labor market flows.

\footnotetext{
${ }^{35}$ Linked employer-employee data sets, such as that recently developed at the Census Bureau, may be particularly well-suited to addressing this question.
} 


\section{DATA APPENDIX: Measuring Gross Flows using CPS Data}

\section{Matching Individuals in the CPS}

Each month, the CPS collects demographic and labor force data from a sample of approximately 50,000 households (60,000 prior to 1996), which yields information for about 120,000 individuals. Households are interviewed eight times over a sixteen-month period: They are interviewed for four consecutive months, not interviewed for the next eight months, and then interviewed again for another four consecutive months. The households are divided into eight approximately equal-sized groups, so that in any month, one-eighth of the households (referred to as a "rotation group") have been interviewed once, one-eighth have been interviewed twice, etc.. Thus, by design, about three-fourths of the households interviewed for the CPS in any one month were interviewed in the previous month as well, and it is possible to match the data for most of the persons in these households across the two months; the remaining quarter of the households are either just entering the sample, or re-entering after an eight-month absence.

To match individuals' records from one month to the next, we use a matching algorithm similar to that used by the BLS in constructing gross flow figures. ${ }^{36}$ We match individual records from one month to the next using the household identification number (augmented by state of residence and serial suffix where household ids are not unique), the person's line number within the household, and sex, race, and age. We require exact matches for all of the variables except age; we accept cases where age decreased by no more than one year or increased by no more than two years. In practice, our algorithm completes about 95 percent of the potential matches.

There are several reasons why a seemingly eligible individual might not match from one month to the next. Among them, the household may move residence, the individual may move out of the household, the members of the household may be unavailable or unwilling to complete the CPS questionnaire, or there could have been coding error. Our estimates of flow rates could be biased to the extent that matching probabilities are correlated with probabilities of leaving or

\footnotetext{
${ }^{36}$ Bleakely, Ferris, and Fuhrer (1999) use a similar method. For an exploration of alternative criteria for matching CPS files, see Madrian and Lefgren (forthcoming).
} 
entering employment. ${ }^{37}$ We label this type of bias "attrition bias" and discuss its effects on our results below. ${ }^{38}$

In addition, the redesigned CPS continues to suffer from "rotation group" bias. The BLS and the Census Bureau have shown that the reported levels of both employment and unemployment may be biased upward for individuals in the first rotation group in the CPS sample. ${ }^{39}$ As shown in table A.1, because the level of employment is overstated for individuals in the first rotation group, the employer separation rates are also biased upwards. In addition, the EE rate and EN rates are considerably higher for employed individuals in the fifth rotation group. For the main analyses of the paper, we drop the first and fifth rotation groups and report results only based on rotation groups two, three, six, and seven.

Table A.1

Employer Separation Rates by First-Month-In-Sample (1998)

\begin{tabular}{|lcccccc|cr|}
\hline \multicolumn{7}{|c}{ Month-In-Sample } \\
Flow & One & Two & Three & Five & Six & Seven & Five & Other \\
\hline EE & 3.12 & 2.76 & 2.56 & 3.03 & 2.74 & 2.60 & 3.08 & 2.66 \\
EU & 1.35 & 1.28 & 1.25 & 1.25 & 1.21 & 1.26 & 1.30 & 1.25 \\
EN & 3.28 & 2.75 & 2.61 & 2.96 & 2.64 & 2.50 & 3.12 & 2.62 \\
\hline
\end{tabular}

\section{$\underline{\text { Attrition Bias }}$}

To explore the extent of attrition bias in our estimates of flow rates and the relationship between the size of the bias and individuals' characteristics, we expanded our main dataset to include nonmatches, including those resulting from noninterviews. The first column of table A.2

\footnotetext{
${ }^{37}$ Bleakley, Ferris, and Fuhrer (1999) found that the probability of not matching was correlated with household characteristics.

${ }^{38}$ See Barkume and Horvath (1995) concerning attrition bias in computing gross flows using pre-1994 data.

${ }^{39}$ U.S Department of Labor (2000, pp.10-9, 16-8 and following).
} 
reports matching rates for various demographic groups for calendar year 1998, and the remaining columns report EE flow rates, EU flow rates, and EN flow rates. ${ }^{40}$ As shown in the table, match rates are lowest for young workers and less educated workers, who also had the highest rates of EE, EU, and EN transitions. In addition, match rates are lowest for unemployed workers; which may simply reflect the relatively higher unemployment rates for younger, less educated workers.

Table A.2

Match Rates (Month 2 to Month 3) by Demographic Characteristics

\begin{tabular}{|lcccc|}
\hline & Match Rate & EE Rate & EU Rate & EN Rate \\
\hline Male & 94.9 & 2.74 & 1.33 & 2.11 \\
Female & 95.4 & 2.59 & 1.15 & 3.23 \\
\hline Ages 16 to 24 & 92.7 & 5.34 & 2.77 & 6.63 \\
Ages 25 to 54 & 95.0 & 2.29 & 1.04 & 1.54 \\
Ages 55 and above & 96.9 & 1.79 & 0.74 & 4.30 \\
\hline White & 95.5 & 2.68 & 1.16 & 2.52 \\
Black & 93.6 & 2.61 & 1.77 & 3.25 \\
\hline Less than high school & 94.6 & 3.49 & 2.63 & 5.83 \\
High school & 95.1 & 2.68 & 1.40 & 2.42 \\
Some college & 95.3 & 2.81 & 1.10 & 2.49 \\
College degree & 95.5 & 2.28 & 0.65 & 1.58 \\
Advanced degree & 95.7 & 1.98 & 0.44 & 1.35 \\
\hline All (unadjusted) & & 2.67 & 1.25 & 2.63 \\
All (adjusted) & & 2.69 & 1.27 & 2.64 \\
\hline
\end{tabular}

${ }^{40} \mathrm{We}$ report only flow rates out of employment in table A.2; the effects of attrition bias on the flows into employment are similar. 
One way to estimate the bias in the aggregate $\mathrm{EE}$ and other job separation rates induced by the correlations between matching rates and gross flow rates is to re-weight the matched sample to account for the different attrition rates for different groups. We divide the observations into cells defined by age groups (16-19, 20-24, 25-34, 35-44, 45-54, 55-64, and 65 plus), sex, race, educational attainment, employment status, month-in-sample, and calendar month, and reweight using the inverse of the match rate for each group. Comparing the final two rows of table A.2, it is apparent that reweighting the sample has little effect on the flow rates out of employment; reweighting raises the EE, EU, and EN transition rate trivially. Tables A.3 and A.4 report the distribution of labor market states in the two months and the flows between them using the two sets of weights. The only notable finding is that the NE and NU flow rates are higher with the alternative weights, which reflects the relative shift in the weights from older individuals with a high probability of remaining in the sample to younger individuals with higher attrition weights.

Table A.3

Labor Market Status as Share of Population (Alternative Weights in Parentheses)

\begin{tabular}{|c|c|c|c|c|c|c|}
\hline \multirow[b]{2}{*}{ Month 1 Status } & \multirow[b]{2}{*}{$\begin{array}{l}\text { Match } \\
\text { Rate } \\
\end{array}$} & \multicolumn{4}{|c|}{ Month 2 Status } & \multirow[b]{2}{*}{$\begin{array}{c}\text { Month } 1 \\
\text { Share } \\
\end{array}$} \\
\hline & & $\begin{array}{c}\text { Employed } \\
\text { (Same) }\end{array}$ & $\begin{array}{c}\text { Employed } \\
\text { (New) }\end{array}$ & Unemployed & $\begin{array}{c}\text { Not in } \\
\text { Labor Force }\end{array}$ & \\
\hline Employed & 95.2 & $\begin{array}{c}59.45 \\
(59.43)\end{array}$ & $\begin{array}{c}1.70 \\
(1.71)\end{array}$ & $\begin{array}{c}0.80 \\
(0.81)\end{array}$ & $\begin{array}{c}1.67 \\
(1.68)\end{array}$ & $\begin{array}{c}63.62 \\
(63.63)\end{array}$ \\
\hline Unemployed & 91.9 & & $\begin{array}{c}0.96 \\
(0.97)\end{array}$ & $\begin{array}{c}1.48 \\
(1.49)\end{array}$ & $\begin{array}{c}0.77 \\
(0.77)\end{array}$ & $\begin{array}{c}3.22 \\
(3.23)\end{array}$ \\
\hline $\begin{array}{l}\text { Not in Labor } \\
\text { Force }\end{array}$ & 95.4 & & $\begin{array}{r}1.56 \\
(1.60) \\
\end{array}$ & $\begin{array}{c}0.79 \\
(0.82) \\
\end{array}$ & $\begin{array}{l}30.82 \\
(30.73) \\
\end{array}$ & $\begin{array}{r}33.16 \\
(33.15) \\
\end{array}$ \\
\hline Month 2 Share & & & & $\begin{array}{r}3.06 \\
(3.11) \\
\end{array}$ & $\begin{array}{r}33.26 \\
(33.19) \\
\end{array}$ & \\
\hline
\end{tabular}


Table A.4

Gross Flows as a Share of Month 1 Status (Alternative Weights in Parentheses)

\begin{tabular}{|c|c|c|c|c|c|c|}
\hline \multirow[b]{2}{*}{ Month 1 Status } & \multirow[b]{2}{*}{$\begin{array}{l}\text { Match } \\
\text { Rate }\end{array}$} & \multicolumn{4}{|c|}{ Month 2 Status } & \multirow[b]{2}{*}{$\begin{array}{c}\text { Month } 1 \\
\text { Share }\end{array}$} \\
\hline & & $\begin{array}{c}\text { Employed } \\
\text { (Same) }\end{array}$ & $\begin{array}{c}\text { Employed } \\
\text { (New) }\end{array}$ & Unemployed & $\begin{array}{c}\text { Not in } \\
\text { Labor Force }\end{array}$ & \\
\hline \multirow[t]{2}{*}{ Employed } & \multirow[t]{2}{*}{95.2} & 93.45 & 2.67 & 1.25 & 2.63 & 63.62 \\
\hline & & $(93.40)$ & $(2.69)$ & $(1.27)$ & $(2.64)$ & $(63.63)$ \\
\hline \multirow[t]{2}{*}{ Unemployed } & \multirow[t]{2}{*}{91.9} & & 30.01 & 46.05 & 23.94 & 3.22 \\
\hline & & & (29.98) & $(46.04)$ & $(23.98)$ & $(3.23)$ \\
\hline Not in Labor & 95.4 & & 4.70 & 2.38 & 92.92 & 33.16 \\
\hline Force & & & $(4.82)$ & $(2.46)$ & $(92.72)$ & $(33.15)$ \\
\hline
\end{tabular}

We consider these to be lower bound estimates of attrition bias, because they are constructed under the assumption that matching is random within demographic groups, and that the only correlation between attrition rates and transition rates stems from composition of the nonmatchers. Instead, individuals who leave the CPS sample because they or their household changed residences are probably more likely to have either changed employer or labor market state than individuals who remain in the sample, after controlling for their demographic characteristics. Accordingly, we further divide nonmatchers into movers - those individuals and households that appear likely to have left the CPS sample because they changed address - and nonmovers - those individuals who either left the sample temporarily or who appear most likely to have not matched because of coding error. Specifically, we classify a nonmatching individual as a mover if either of the following is true: (1) There is a replacement household in the second month in our sample; ${ }^{41}$ or (2) The individual's entire household is not interviewed in the second month and does not match in the third month; or (3) The individual is not interviewed in the second month and does not match in the third month, although other members of the household remain in the sample. We classify individuals as nonmovers if either of the following conditions

\footnotetext{
${ }^{41}$ Because we excluded the first and fifth rotation groups from our sample, the second month in our sample is actually the third month in the CPS sample.
} 
is true: (1) The individual that is absent in the second month has a successful match from the first to the third month; or (2) the individual appears to have been interviewed in the second month, but for some unknown reason does not match from the first to the second month. Under this scheme, 48 percent of the nonmatches in 1998 are classified as movers. Of these movers, 18 percent are in households that were replaced in the second month, 46 percent were in households that were not interviewed in month 2 , and the remaining 36 percent were individuals who appear to have moved out of households that continued in the CPS sample. Similarly, we classified about 45 percent of the nonmatches who were employed in month 1 as movers. If we assume that all employed movers separate from their first-month job, the true job leaving rate would be about 2-1/4 percentage points higher than the 6.6 percent reported in the body of the paper. This should be considered as an upper bound estimate for the size of the attrition bias, as it is likely that many movers did not change jobs or leave employment-especially those who move to a new location within the same labor market area. 


\section{References}

Abowd, John M. and Arnold Zellner, "Estimating Gross Labor-Force Flows," Journal of Business and Economic Statistics 3(3), June 1985, pp. 254-83.

Akerlof, George A., Andrew K. Rose, and Janet L. Yellen, "Job Switching and Job Satisfaction in the U.S. Labor Market," Brookings Papers on Economic Activity 2, 1988, p.495-592.

Albaek, K. and B.E. Sorensen, "Worker flows and job flows in Danish manufacturing, 1980-91," Economic Journal 108(451), November 1998, pp.1750-1771.

Anderson, Patricia M., and Simon M. Burgess, "Empirical Matching Functions: Estimation and Interpretation Using State-Level Data," Review of Economics and Statistics 82(1), February 2000, pp.93-102.

Anderson, Patricia M., and Bruce D. Meyer, "The Extent and Consequences of Job Turnover," Brookings Papers on Economic Activity: Microeconomics, 1994, pp. 177-236.

Bancroft, Gertrude and Stuart Garfinkle, “Job Mobility in 1961," US Department of Labor, Special Labor Force Report 35, August 1963.

Bansak, Cynthia, and Steven Raphael, "Have Employment Relationships in the United States Become Less Stable?" University of California, San Diego, Discussion Paper 98-15, June 1998.

Barkume, Anthony J. and Francis W. Horvath, "Using gross flows to explore movements in the labor force," Monthly Labor Review 118(4), April 1995, pp.28-35.

Bernhardt, Annette, Martina Morris, Mark S. Hancock, and Marc A. Scott, "Trends in Job Instability and Wages for Young Adult Men," Journal of Labor Economics 17(4), Part 2, October 1999, pp.S65-S90.

Bester, H., "Incentive-Compatible Long-Term Contracts and Job Rationing," Journal of Labor Economics 7(2), 1989, pp.238-255.

Blanchard, Olivier and Peter Diamond, "The Beveridge Curve," Brookings Papers on Economic Activity 1, 1989, p.1-60.

Blanchard, Olivier and Peter Diamond, "The Cyclical Behavior of Gross Flows of U.S. Workers," Brookings Papers on Economic Activity 2, 1990, p.85-156.

Bleakley, Hoyt, Anne E. Ferris, and Jeffrey C. Fuhrer, "New Data on Worker Flows During Business Cycles," New England Economic Review, July/August 1999, pp.49-76.

Booth, Alison L., Marco Francesconi, and Carlos Garcia-Serrano, "Job Tenure and Job Mobility in Britain," Industrial and Labor Relations Review 53(1), October 1999, pp.43-70. 
Bull, C., "The Existence of Self-Enforcing Implicit Contracts," Quarterly Journal of Economics 102(1), 1987, pp.147-159.

Burda, M. and C. Wyplosz, "Gross Worker Flows and Job Flows in Europe," European Economic Review 38(6), June 1994, pp.1287-1315.

Burdett, Kenneth, "A Theory of Employee Job Search and Quit Rates," American Economic Review, 68(1), March 1978, pp. 212-220.

Burgess, S.M., “The Flow Into Unemployment in Britain,” Economic Journal 102(413), July 1992, pp.888-895.

Burgess, S.M., "Matching Models and Labor-market Flows," European Economic Review 38(34), April 1994, pp.809-816 .

Burgess, Simon, Julia Lane, and David Stevens, "Job Flows, Worker Flows, and Churning," Journal of Labor Economics 18(3), July 2000, pp. 473-502.

Campbell, Jeffrey R. and Kenneth N. Kuttner, "Macroeconomic Effects of Employment Reallocation," Carnegie-Rochester Conference Series on Public Policy, Volume 44, June 1996. pp. 87-116.

Christofides, L.N., and C.J. McKenna, "Unemployment Insurance and Job Duration in Canada," Journal of Labor Economics 14(2), April 1996, pp.286-312.

Cole, H.L., and R. Rogerson R, "Can the Mortensen-Pissarides matching model match the business-cycle facts?” International Economic Review 40(4), November 1999, pp.933-959.

Davis, Steven J. and John Haltiwanger, "Measuring Gross Worker and Job Flows," in Labor Statistics Measurement Issues, edited by John Haltiwanger, Marilyn Manser and Robert Topel, (Chicago: University of Chicago Press), 1999a, pp. 77-122.

Davis, Steven J., and John Haltiwanger, "On the driving forces behind cyclical movements in employment and job reallocation," American Economic Review 89(5), December 1999b, pp. 1234-1258.

Davis, Steven J., John C. Haltiwanger, and Scott Schuh, Job Creation and Job Destruction, Cambridge, Massachusetts: The MIT Press, 1996.

Dippo, Cathryn, Anne Polivka, Kathleen Creighton, Donna Kostanich, and Jennifer Rothgeb, (1994) "Redesigning A Questionnaire For Computer-Assisted Data Collection: The Current Population Survey Experience," CPS Research Documentation Report, 1994. 
Eriksson, Stefan, and Nils, Gottfries, "Ranking of Job Applicants, On-the-Job Search and Persistent Unemployment," manuscript, Department of Economics, Uppsala University, March 2000.

Fallick, Bruce C., "The Hiring of New Labor by Expanding Industries," Labour Economics 3(1), March 1996, pp.25-42.

Farber, Henry S., "The Analysis of Interfirm Worker Mobility," Journal of Labor Economics 12(4), October 1994, pp.554-593.

Farber, Henry S., "Mobility and Stability: the Dynamics of Job Change in Labor Markets," Handbook of Labor Economics, Volume 3B, edited by Orley Ashenfelter and David Card, 1999, pp. 2439-2480.

Figura, Andrew, "Is Reallocation Related to the Cycle? A Look at Permanent and Temporary Job Flows", manuscript, Federal Reserve Board, February, 2001.

Galizzi, M. and K. Lang, "Relative Wages, Wage Growth, and Quit Behavior," Journal of Labor Economics 16(2), April 1998, pp.367-391.

Gottschalk, Peter, and Robert Moffitt, "Changes in Job Instability and Insecurity Using Monthly Survey Data,” Journal of Labor Economics 17(4), Part 2, October 1999, pp.S91-S126.

Gregg, Paul and Wadsworth, Jonathan, "A Short History of Labour Turnover, Job Tenure, and Job Security, 1975-93," Oxford Review of Economic Policy 11(1), April 1995, pp. 73-90.

Hamermesh, Daniel S., Wolter H. J. Hassink, and Jan C. van Ours, "New Facts about FactorDemand Dynamics: Employment, Jobs, and Workers," National Bureau of Economic Research, Working Paper No. 4625, 1994.

Hashimoto, M. and J. Raisian, "Employment Tenure and Earnings Profiles in Japan and the United States,” American Economic Review 75(4), 1985, pp.721-735.

Jackman, R., R. Layard, and C. Pissarides, "On Vacancies, " Oxford Bulletin of Economics and Statistics 51(4), November 1989, pp.377-94.

Jaeger, David A. and Ann Huff Stevens, "Is Job Stability in the United States Falling? Reconciling Trends in the Current Population Survey and Panel Study of Income Dynamics," Journal of Labor Economics 17(4), Part 2, October 1999, pp.S1-S28.

Lane, Julia, David Stevens, and Simon Burgess, "Worker and Job Flows," Economics Letters 51(1), April 1996, pp.109-13.

Lilien, David M., "Sectoral Shifts and Cyclical Unemployment," Journal of Political Economy 90(4), 1982, pp.777-793. 
Madrian, Brigitte C., and Lar John Lefgren, "An Approach to Longitudinally Matching Current Population Survey Respondents," Journal of Economic and Social Measurement, forthcoming.

Marston, Stephen T. , "Employment Instability and High Unemployment Rates," Brookings Papers on Economic Activity 1:1976, pp.169-203.

Mattila, J. Peter, "Job Quitting and Frictional Unemployment," American Economic Review 64(1), March 1974, pp.235-9.

Meisenheimer, Joseph R. II and Randy E. Ilg, "Looking for a 'Better' job: Job Search Activity of the Employed," Monthly Labor Review, September 2000, pp. 3-14.

Merz, Monika, "Heterogeneous Job-Matches and the Cyclical Behavior of Labor Turnover," Journal of Monetary Economics 43(1), February 1999, pp. 91-124.

Monks, James and Steven D. Pizer, "Trends in Voluntary and Involuntary Job Turnover," Industrial Relations 37(4), October 1998, pp. 440-59.

Mortensen, D. T., "The Cyclical Behavior of Job and Worker Flows," Journal of Economic Dynamics and Control 18(6), November 1994, pp.1121-42.

Mortensen, D.T., and C.A. Pissarides, "Job Creation and Job Destruction in the Theory of Unemployment," Review of Economic Studies 61(3), July 1994, pp.397-415.

Neumark, David, Daniel Polsky, and Daniel Hansen, "Has Job Stability Declined Yet? New Evidence for the 1990s," Journal of Labor Economics 17(4), Part 2, October 1999, pp.S29-S64.

Parsons, D. O., "Quit Rates Over Time: A Search and Information Approach," American Economic Review, 63(2), June 1973, pp. 390-401.

Parsons, D. O., "The Job Search Behavior of Employed Youth" Review of Economics and Statistics 73(4), 1991, pp.597-604.

Petrongolo, Barbara and Christopher A. Pissarides, "Looking into the Black Box: A Survey of the Matching Function," Center for Economic Policy Research, CEPR Discussion Paper No. 2409, 2000.

Pissarides, C.A., "Search Unemployment with On-the-Job Search," Review of Economic Studies 61(3), July 1994, pp.457-75.

Polsky, Daniel, "Changing Consequences of Job Separation in the United States," Industrial and Labor Relations Review 52(4), July 1999, pp.565-80.

Poterba, James M. and Lawrence H. Summers, "Reporting Errors and Labor Market Dynamics," Econometrica 54(6), November 1986, pp. 1319-38. 
Royalty, Anne Beeson, "Job-to-Job and Job-to-Nonemployment Turnover by Gender and Education Level," Journal of Labor Economics 16(2), April 1998, pp.392-443.

Ruhm, C.J., "Bridge Jobs and Partial Retirement," Journal of Labor Economics 8(4), 1990, pp.482-501.

Stewart, Jay, "Recent Trends in Job Stability and Job Security," manuscript, Bureau of Labor Statistics, December 1999.

Tobin, James. "Inflation and Unemployment," American Economic Review, 62(1), March 1972, pp. 1-18.

Topel, R.H., and M.P. Ward, "Job Mobility and the Careers of Young Men," Quarterly Journal of Economics 107(2), May 1992, pp.439-79.

Ureta, M., "The Importance of Lifetime Jobs in the United States Economy, Revisited," American Economic Review 82(1), March 1992, pp.322-35.

U.S Department of Labor, Bureau of Labor Statistics and U.S. Department of Commerce, Economics and Statistics Administration, U.S. Census Bureau, Current Population Survey Technical Paper 63: Design and Methodology, 2000.

Van Ours, J.C., "An Empirical Note on Employed and Unemployed Job Search," Economics Letters 49(4), October 1995, pp.447-452. 
Figure 1
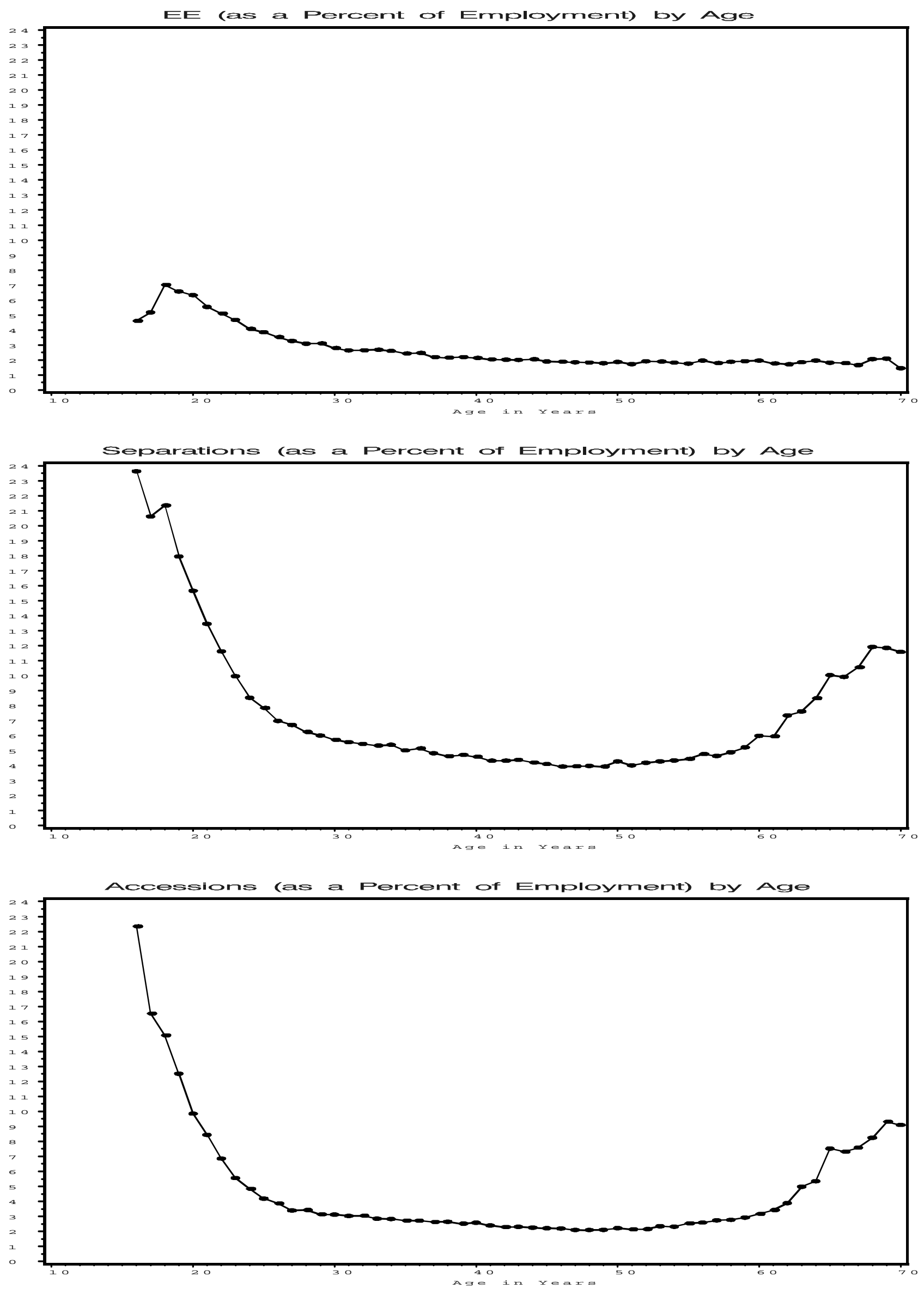
Figure 2

(Percent of Population)
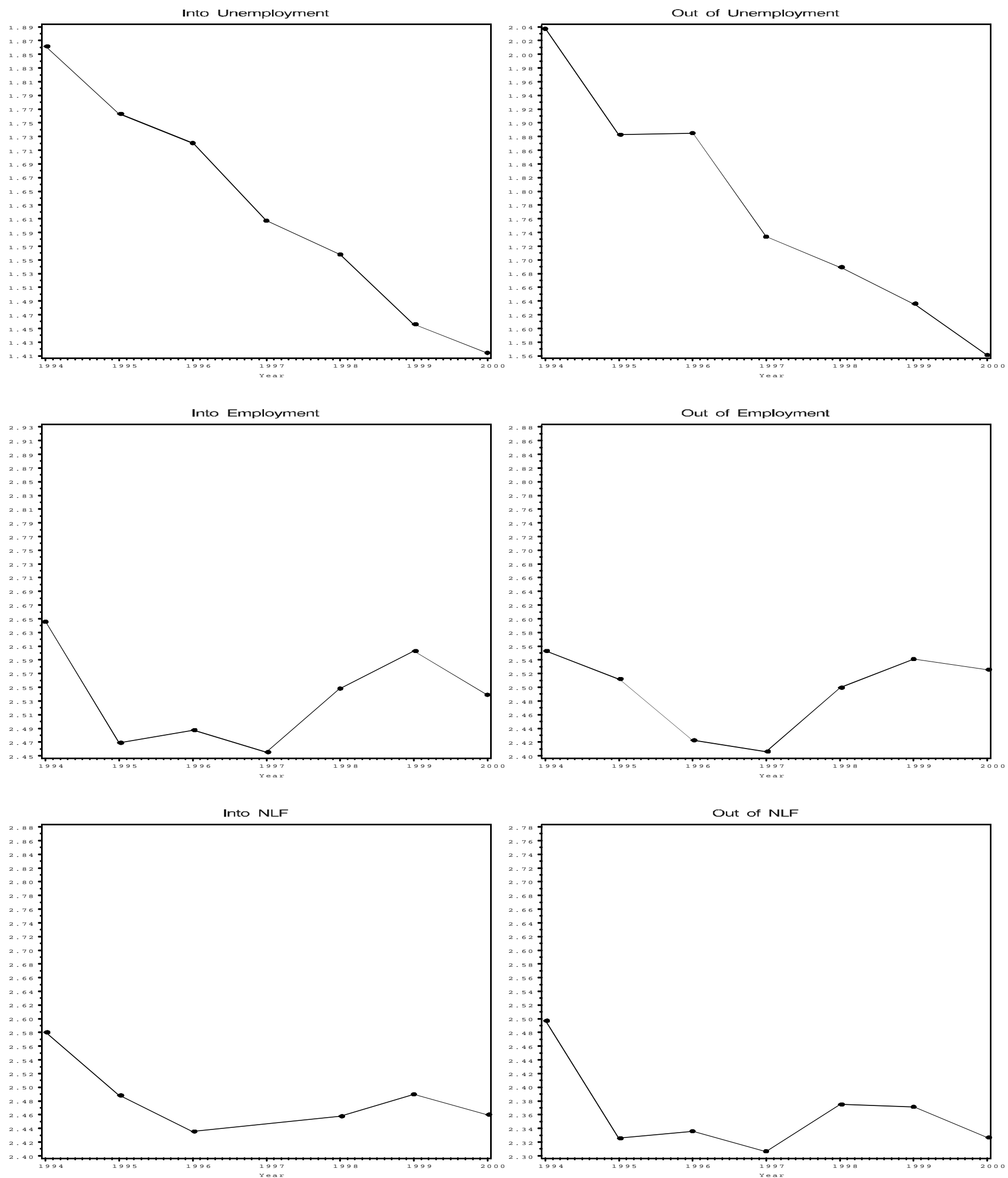
Figure 3

(Percent of Population)
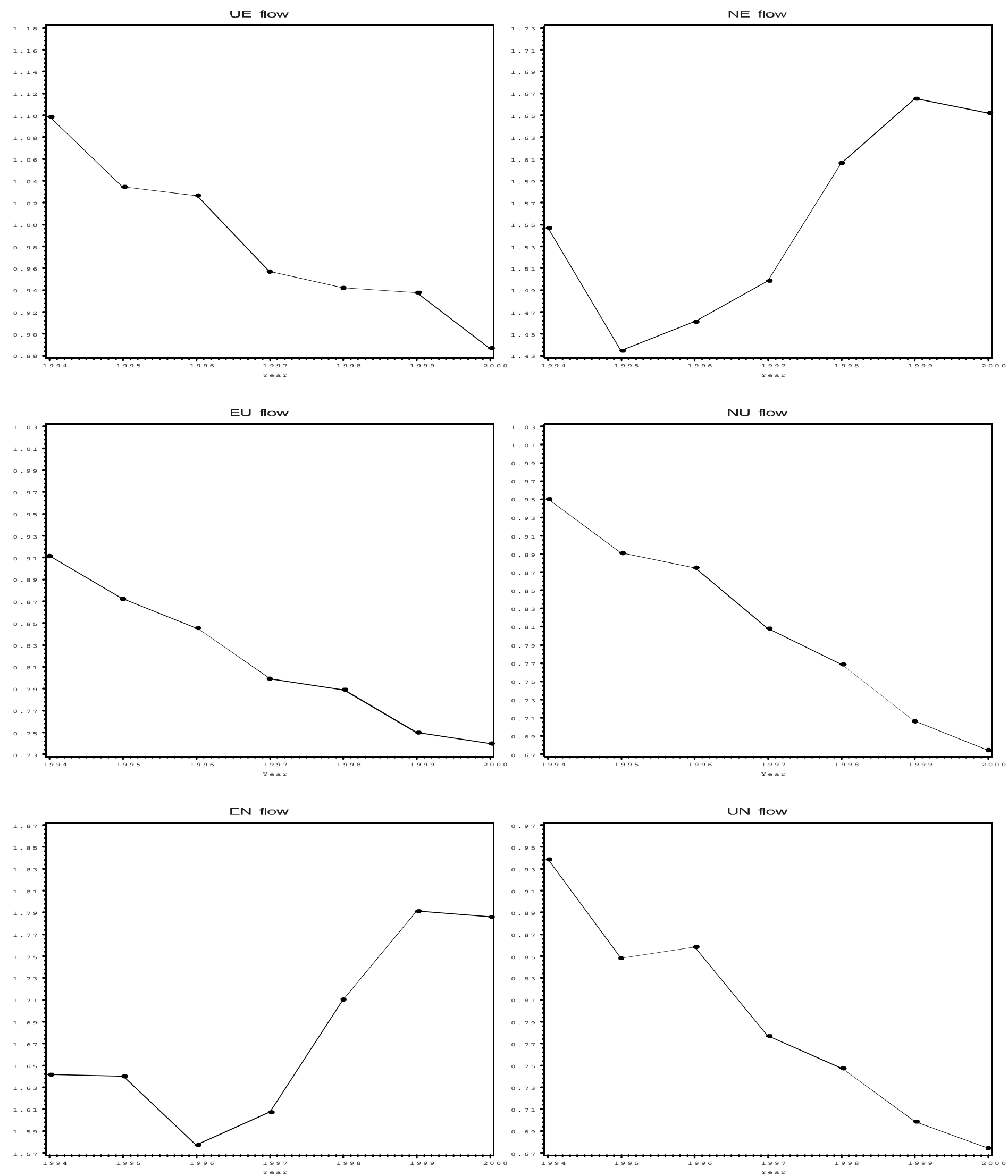


$$
\square
$$

